\title{
Amphibole-melt disequilibrium in silicic melt of the Aso-4 caldera-forming eruption at Aso Volcano, SW Japan
}

\author{
Hidemi Ishibashi ${ }^{1 *}, Y_{\text {Kkiko Suwa }}{ }^{1}$, Masaya Miyoshi ${ }^{2}$, Atsushi Yasuda ${ }^{3}$ and Natsumi Hokanishi ${ }^{3}$
}

\begin{abstract}
The most recent and largest caldera-forming eruption occurred at 90 ka at Aso Volcano, SW Japan, and is known as the "Aso-4 eruption."We performed chemical analyses of amphibole phenocrysts from Aso-4 pyroclasts collected from the initial and largest pyroclastic unit (4I-1) of the eruption to infer the composition-temperature-pressure conditions of the melt that crystallized amphibole phenocrysts. Each amphibole phenocryst is largely chemically homogeneous, but inter-grain chemical variation is observed. Geothermometry, geobarometry, and melt- $\mathrm{SiO}_{2}$ relationships based on amphibole single-phase compositions reveal that most amphibole phenocrysts were in equilibrium with hydrous melt comprising $\sim 63-69 \mathrm{wt} \% \mathrm{SiO}_{2}\left(\mathrm{SiO}_{2}^{\text {melt }}\right.$ ) at $910-950{ }^{\circ} \mathrm{C}$, although several grains were crystallized from more mafic and higher-temperature melts $\left(\sim 57-60.5 \mathrm{wt} \% \mathrm{SiO}_{2}\right.$ and $\left.965-980^{\circ} \mathrm{C}\right)$. The amphibole temperatures are comparable with those previously estimated from two-pyroxene geothermometry, but are much higher than temperatures previously estimated from Fe-Ti oxide geothermometry. The estimated $\mathrm{SiO}_{2}^{m e l t}$ contents are lower than that of the host melt in the 4I-1 pyroclasts. Chemical and thermal disequilibrium between the amphibole rims and the host melt, as well as intra-grain homogeneity and inter-grain heterogeneity of amphibole compositions, suggests that these amphiboles were incorporated into the host melt immediately prior to the caldera-forming eruption. Our results suggest that the amphibole phenocrysts, and perhaps some of the pyroxene and plagioclase phenocrysts, were derived from a chemically and thermally zoned crystal mush layer that had accumulated beneath the chamber of the host 4I-I melt. Amphibole geobarometry indicates a crystallization depth of $\sim 13.9 \pm 3.5 \mathrm{~km}$, which is consistent with the present-day magma chamber depth beneath the volcano as inferred from geophysical observations. The results suggest that the depth of the post-caldera magma plumbing system is strongly influenced by a relic magma reservoir related to a previous caldera-forming eruption.
\end{abstract}

Keywords: Amphibole, Aso Volcano, Caldera, Crystal mush, Thermobarometry

\section{Introduction}

Caldera-forming eruptions are the most violent and catastrophic volcanic phenomena and have a significant influence on the surface environment on a global scale (e.g., Miller and Wark 2008; Druitt et al. 2012). Therefore, it is critical to understand the causes and processes of caldera-forming eruptions. To address this issue, quantifying the pre-eruptive physicochemical conditions of

\footnotetext{
*Correspondence: ishibashi.hidemi@shizuoka.ac.jp

${ }^{1}$ Department of Geoscience, Faculty of Science, Shizuoka University,

Ohya 836, Suruga-ku, Shizuoka 422-8529, Japan

Full list of author information is available at the end of the article
}

magma is imperative because this has a significant control on magma ascent processes and eruption dynamics (e.g., Wark et al. 2007; Ruprecht and Bachmann 2010). Textural and chemical analyses of phenocryst phases are valuable methods for deciphering pre-eruptive magmatic conditions (e.g., Ginibre et al. 2007; Cooper 2017).

Igneous amphibole has been the focus of many recent studies (e.g., De Angelis et al. 2013; Shane and Smith 2013; Erdmann et al. 2014; Kiss et al. 2014). Empirical equations have been proposed that reliably relate singlephase compositions of amphibole with the temperature (T) and pressure $(\mathrm{P})$ conditions of crystallization and the $\mathrm{SiO}_{2}$ content of coexisting silicate melt $\left(\mathrm{SiO}_{2}^{\text {melt }}\right)$ (Ridolfi 
et al. 2010; Ridolfi and Renzulli 2012; Putirka 2016). By using empirical equations, the $\mathrm{T}, \mathrm{P}$, and $\mathrm{SiO}_{2}^{\text {melt }}$ related to amphibole crystallization can be estimated without assuming equilibrium between phases. In addition, the empirical equations enable recognition of disequilibrium between amphibole and other phases (Putirka 2016). Geothermobarometric methods based on multiple phases require a priori assumptions of equilibria between coexisting phases. Although disequilibrium between coexisting phases causes large errors in thermobarometric results, it is not easy to evaluate equilibrium/ disequilibrium between coexisting phases. Empirical thermobarometric and chemometric equations based on a single-phase composition of amphibole are particularly valuable because they do not assume inter-phase equilibrium (Putirka 2016) and are hence useful in detecting phase disequilibrium between amphibole and other phases. The detection of phase disequilibrium in magma is essential in reconstructing the pre-eruptive processes of caldera-forming eruptions based on petrological information recorded in pyroclasts.

Aso Volcano, the second-largest caldera volcano in Japan $(25 \times 18 \mathrm{~km})$, was formed by four caldera-forming eruptions (Aso-1 to Aso-4) that occurred during the period 266-89 ka (Ono and Watanabe 1985). The Aso-4 eruption represents the most recent caldera-forming eruptive cycle and produced voluminous pyroclastic products $\left(>600 \mathrm{~km}^{3}\right.$, VEI 7; Committee for Catalog of Quaternary Volcanoes in Japan 1999). The Aso-4 pyroclastic flow deposits are deposited throughout the central and northern parts of Kyushu Island and crossed the sea to reach the western part of Honshu Island (Ono and Watanabe 1985). The Aso-4 co-ignimbrite ash fall deposit (15 cm thick) is found at Abashiri in eastern Hokkaido, $\sim 1700 \mathrm{~km}$ from Aso Volcano (Machida and Arai 2003). Among the four caldera-forming cycles, only the Aso-4 pyroclastic products contain amphibole phenocrysts (Watanabe 2001; Kaneko et al. 2007). On the basis of petrological and isotopic data, Hunter (1998) and Kaneko et al. (2007) showed that the Aso-4 magma is compositionally diverse (basaltic to rhyolitic) and was generated by several intra-crustal processes (magma mixing, crustal assimilation, and fractional crystallization) within a largezoned magma chamber. However, geothermobarometry studies of the Aso-4 magma are limited, and hence, the detailed pre-eruptive magmatic processes and conditions remain debated.

Application of amphibole single-phase-based thermobarometric and chemometric equations to Aso-4 amphibole phenocrysts provides important constraints on the magmatic processes and conditions immediately prior to the largest caldera-forming eruption at Aso Volcano. We investigated the chemical compositions of amphibole phenocrysts in the Aso-4 pyroclastic products and applied the amphibole-based empirical thermobarometer and melt- $-\mathrm{SiO}_{2}$ meter to quantify the $\mathrm{P}-\mathrm{T}-\mathrm{SiO}_{2}^{\text {melt }}$ conditions of amphibole crystallization. Our results indicate disequilibrium between the amphibole phenocrysts and the host groundmass melt of the Aso- 4 silicic magma.

\section{Geology of Aso Volcano and the Aso-4 eruption}

Aso Volcano is located in the volcanic front on Kyushu Island, southwest Japan-Ryukyu arc (Fig. 1). The Aso Caldera was formed by four pyroclastic flow eruptions: Aso-1 $(266 \pm 14 \mathrm{ka})$, Aso-2 $(141 \pm 5 \mathrm{ka})$, Aso-3 $(123 \pm 6 \mathrm{ka})$, and Aso-4 (89 $\pm 7 \mathrm{ka})$ (Ono and Watanabe 1985; K-Ar ages from Matsumoto et al. 1991). The total volumes of these four pyroclastic flow deposits (including co-ignimbrite ash fall deposits) are estimated as 50 , $50,>150$, and $>600 \mathrm{~km}^{3}$, respectively (Committee for Catalog of Quaternary Volcanoes in Japan 1999). The caldera walls consist of pre-Aso volcanic rocks that pre-date the caldera-forming Aso-1 eruption (Ono and Watanabe 1985; Watanabe et al. 1989). The Aso-1 to Aso-4 pyroclastic flow deposits were widely deposited over the preexisting pre-Aso volcanic rocks. Post-caldera volcanism commenced soon after the last caldera-forming eruption at $89 \mathrm{ka}$ (Ono and Watanabe 1985; Miyoshi et al. 2012).

The Aso-4 pyroclastic eruption is divided into two subcycles that are characterized by a progression from silicic to mafic magma (Ono and Watanabe 1983; Kaneko et al. 2007). On the basis of the lithological and petrological features of the pyroclastic flow deposits, the first (I) and second (II) sub-cycles of the Aso-4 eruption are divided into the following units (in stratigraphic order): 4I-1, 4I-2, and 4I-3; and 4II-1, 4II-2, and 4II-3 (Kaneko et al. 2007). The volumes of these pyroclastic flow units are estimated as follows: $4 \mathrm{I}-1>60 \mathrm{~km}^{3}$; $4 \mathrm{I}-2>4 \mathrm{~km}^{3} ; 4 \mathrm{I}-3=\sim 0.5 \mathrm{~km}^{3}$; $4 \mathrm{II}-1=\sim 10 \mathrm{~km}^{3} ; 4 \mathrm{II}-2=5 \mathrm{~km}^{3}$; and $4 \mathrm{II}-3=\sim 0.2 \mathrm{~km}^{3}$ (Ono et al. 1977; Watanabe 1978; Kamata 1997; Kaneko et al. 2007). Kaneko et al. (2007) argued that the magma chambers that fed the Aso-4 sub-cycles were compositionally zoned from mafic (lower) to silicic (upper). Based on mineralogical and geochemical data, they suggested that the andesitic-dacitic products (the pyroclastic units other than 4I-1) are hybrids of the upper and lower magmas (Kaneko et al. 2007). The pre-eruptive depth of the Aso-4 silicic magma was estimated to be deeper than $3 \mathrm{~km}$ on the basis of the water content of the melt and the $\mathrm{H}_{2} \mathrm{O}$ solubility equation (Kaneko et al. 2007).

\section{Methods \\ Analyzed samples}

Two rock samples were collected from Unit 4I-1 of the Aso-4 pyroclastic deposits. Unit 4I-1 was formed from the initial silicic pyroclastic flow $\left(\sim 69 \mathrm{wt} \%\right.$ bulk $\mathrm{SiO}_{2}$ 


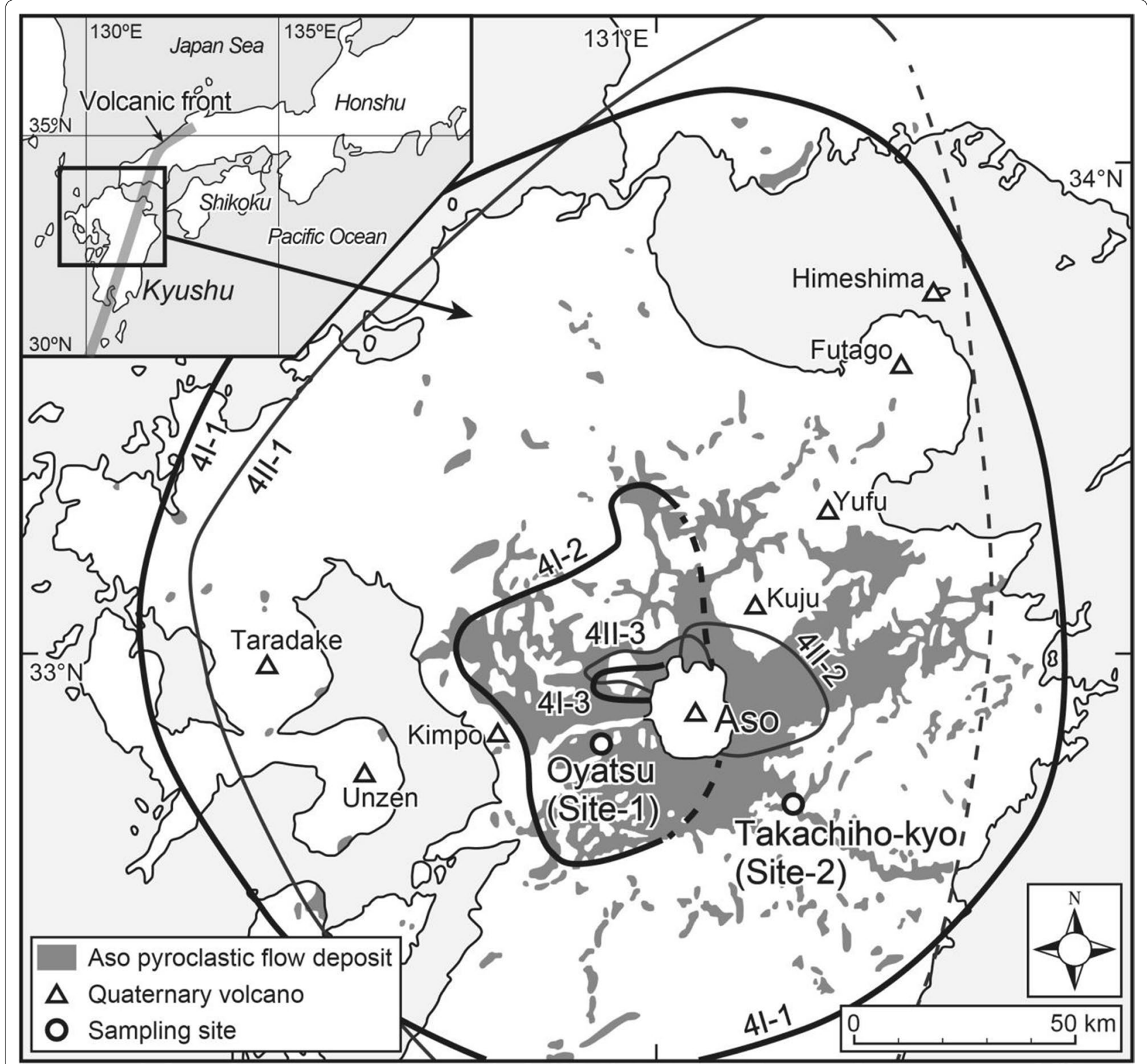

Fig. 1 Distribution of Aso-4 pyroclastic deposits and sampling sites (after Ono and Watanabe 1985; Kaneko et al. 2007). Solid lines show the distribution areas of Aso-4 pyroclastic flow units. Dashed lines show the estimated distribution areas of the units (Kaneko et al. 2007)

and $\sim 72 \mathrm{wt} \%$ melt $\mathrm{SiO}_{2}$ ) and was the most voluminous unit erupted during the Aso- 4 cycle $\left(>60 \mathrm{~km}^{3}\right.$; Kaneko et al. 2007). Total sum of the 4I-1 deposit and the coignimbrite ash fall deposit $\left(>400 \mathrm{~km}^{3}\right)$ is almost $75 \%$ of the total volume of Aso- 4 cycle. The dense rock equivalent volume of silicic magma which existed before the 4I-1 eruption is estimated to be more than $200 \mathrm{~km}^{3}$ (Kaneko et al. 2007). The samples were selected to investigate the magmatic processes and conditions in the upper part of the magma chamber immediately before the first sub-cycle of Aso-4. Sample 4I-1p is a pumice clast collected from a non-welded pumice flow deposit at Site-1 (Oyatsu, $\sim 23 \mathrm{~km}$ west of the center of Aso Caldera). Sample 4I-1w was collected from the densely welded tuff at Site-2 (Takachiho-kyo, $\sim 30 \mathrm{~km}$ southeast of the center of Aso Caldera; Fig. 1). The amphibole phenocrysts in these samples were fresh enough for chemical analysis. Polished thin sections were made for backscattered electron (BSE) imaging and analysis by electron probe microanalyzer (EPMA). 


\section{Analytical methods}

BSE imaging of amphibole phenocrysts from the Aso-4 pyroclast samples was performed using a field emission EPMA (JEOL JXA-8530FPlus) at the Earthquake Research Institute, University of Tokyo, Japan (ERI). Major-element compositions were measured using an EPMA (JEOL-8800R) at ERI. For compositional analyses, the accelerating voltage, analytical current, and beam size conditions were $15 \mathrm{kV}, 12 \mathrm{nA}$, and $1 \mu \mathrm{m}$, respectively. The stoichiometric calculations of the amphibole are based on the 13-cation model of Leake et al. (1997). The $1 \sigma$ relative errors of the element measurements are $<0.7$ rel.\% for $\mathrm{Si} ;<1$ rel.\% for $\mathrm{Al}, \mathrm{Fe}, \mathrm{Mg}$, and $\mathrm{Ca} ;<5$ rel.\% for Ti and $\mathrm{Na} ;<10$ rel.\% for $\mathrm{K}$; and $<20$ rel.\% for $\mathrm{Mn}$. The $1 \sigma$ relative error for $\mathrm{Cl}$ is $<10$ rel.\% for $\mathrm{Cl}$ contents of $\sim 0.1 \mathrm{wt} \%$ (Nagasaki et al. 2017). In addition, we used SEM (Hitachi S-3400 N) equipped with EDS (Oxford Instruments X-MAX50) at Shizuoka University for phase identification of mineral inclusions in amphiboles.

\section{Amphibole thermobarometry and chemometry}

Empirical equations have been proposed to quantitatively relate the physical and chemical conditions of a silicate melt in equilibrium with calcic amphibole (including T, $\mathrm{P}$, and $\mathrm{SiO}_{2}^{\text {melt }}$ ) with the single-phase composition of amphibole (Ridolfi et al. 2010; Ridolfi and Renzulli 2012; Putirka 2016). The empirical equations were formulated based on high-P-T equilibrium experiments using natural volcanic rocks as starting materials. In the present study, the P-T$\mathrm{SiO}_{2}^{\text {melt }}$ conditions of silicate melts in equilibrium with amphiboles were estimated using the empirical equations based on amphibole composition. These conditions can be estimated using these equations without assuming equilibrium between amphibole and other phases, which enables us to recognize disequilibrium between these phases. Although several geothermobarometers have been proposed based on element partitioning between amphibole and plagioclase (e.g., Blundy and Holland 1990; Holland and Blundy 1994; Molina et al. 2015) and between amphibole and silicate melt (e.g., Putirka 2016), they all require the assumption of equilibrium between amphibole and other phases. These models therefore have increased errors associated with $\mathrm{P}-\mathrm{T}$ estimates if amphibole and other phases are in disequilibrium. Therefore, we calculated the $\mathrm{P}-\mathrm{T}-\mathrm{SiO}_{2}^{\text {melt }}$ conditions of silicate melts in equilibrium with amphiboles using the empirical equations based on amphibole composition.

In this study, we used the independent thermometric equation proposed by Putirka (2016) (Eq. 1) to estimate amphibole crystallization temperatures:

$$
\begin{aligned}
\mathrm{T}\left({ }^{\circ} \mathrm{C}\right)= & 1781-132.74 \times\left[\mathrm{Si}^{\mathrm{Amp}}\right] \\
& +116.6 \times\left[\mathrm{Ti}^{\mathrm{Amp}}\right]-69.41 \\
& \times\left[\mathrm{Fe}_{t}^{\mathrm{Amp}}\right]+101.62 \times\left[\mathrm{Na}^{\mathrm{Amp}}\right],
\end{aligned}
$$

where $\mathrm{Si}^{\mathrm{Amp}}, \mathrm{Ti}^{\mathrm{Amp}}, \mathrm{Fe}_{\mathrm{t}}^{\mathrm{Amp}}$, and $\mathrm{Na}^{\mathrm{Amp}}$ are the numbers of cations in amphibole calculated on the basis of 23 atoms and $\mathrm{Fe}_{\mathrm{t}}^{\mathrm{Amp}}$ is the total number of Fe cations as $\mathrm{Fe}^{2+}$. Although Putirka (2016) proposed pressure-dependent and pressure-independent models, the temperature estimation errors are similar for the two models; i.e., the mean and standard deviation of the difference between estimated and experimental temperatures are $3.2{ }^{\circ} \mathrm{C}$ and $28{ }^{\circ} \mathrm{C}$ for the P-dependent model, respectively, and $0.4{ }^{\circ} \mathrm{C}$ and $30{ }^{\circ} \mathrm{C}$ for the P-independent model, respectively. Putirka (2016) argued that these models are the most accurate of the existing amphibole geothermometers. In this study, we use the P-independent model to estimate the crystallization temperatures of the analyzed amphiboles.

Ridolfi and Renzulli (2012) and Putirka (2016) proposed empirical equations to calculate the $\mathrm{SiO}_{2}$ content of a hydrous silicate melt in equilibrium with amphibole $\left(\mathrm{SiO}_{2}^{\text {melt }}\right)$ from the amphibole composition and temperature. The two models yield consistent results and reproduce $\mathrm{SiO}_{2}^{\text {melt }}$ within \pm 3.6 wt\% (Putirka 2016). In this study, we used the model of Putirka (2016):

$$
\begin{aligned}
\mathrm{SiO}_{2}^{\text {melt }}= & 751.95-0.4 \times T\left({ }^{\circ} \mathrm{C}\right)-278,000 / T\left({ }^{\circ} \mathrm{C}\right) \\
& -9.184 \times\left[\mathrm{Al}^{T-\mathrm{Amp}}\right],
\end{aligned}
$$

where $\mathrm{Al}^{\mathrm{T}-\mathrm{Amp}}$ is the amount of $\mathrm{Al}$ in amphibole when calculated on the basis of $23 \mathrm{O}$ atoms and $\mathrm{SiO}_{2}^{\text {melt }}$ is the $\mathrm{SiO}_{2}$ content (wt\%) in hydrous silicate melt including the total mass of $\mathrm{H}_{2} \mathrm{O}$.

Ridolfi et al. (2010) and Ridolfi and Renzulli (2012) proposed empirical barometric equations based on amphibole composition. The model of Ridolfi et al. (2010) is a function of the $\mathrm{Al}$ content in amphibole, whereas the models of Ridolfi and Renzulli (2012) depend on both the $\mathrm{Al}$ content and the concentration of other elements in amphibole, as shown in the following equations (at pressure conditions of $130 \mathrm{MPa}<P<500 \mathrm{MPa}$ ):

$$
\begin{aligned}
\ln P(\mathrm{MPa})= & 38.723-(2.6957 \times \mathrm{Si})-(2.3565 \times \mathrm{Ti}) \\
& -(1.3006 \times \mathrm{Al})-(2.7780 \times \mathrm{Fe}) \\
& -(2.4838 \times \mathrm{Mg})-(0.6614 \times \mathrm{Ca}) \\
& -(0.2705 \times \mathrm{Na})+(0.1117 \times E)
\end{aligned}
$$




$$
\begin{aligned}
P(\mathrm{MPa})= & 24023-(1925.3 \times \mathrm{Si})-(1720.6 \times \mathrm{Ti}) \\
& -(1478.5 \times \mathrm{Al})-(1843.2 \times \mathrm{Fe}) \\
& -(1746.9 \times \mathrm{Mg})-(158.28 \times \mathrm{Ca}) \\
& -(40.444 \times \mathrm{Na})+(14.389 \times \mathrm{K}) .
\end{aligned}
$$

In these equations, the cation numbers in amphibole are calculated based on the 13-cation model of Leake et al. (1997).

The reliability of amphibole barometry is still debated. Erdmann et al. (2014) and Putirka (2016) quantitatively examined the reliability of the models of Ridolfi et al. (2010) and Ridolfi and Renzulli (2012) and proposed that the pressures estimated using the amphibole barometers were artifacts reflecting the bulk magma compositions and concluded that the models are untenable. However, Nagasaki et al. (2017) re-examined the reliabilities of Eqs. 3 and 4 using the compiled dataset of high-P-T equilibrium experiments selected by Putirka (2016) and showed that these equations can be used to roughly estimate the pressure within a $1 \sigma$ error of $\pm 85 \mathrm{MPa}$ under the limited conditions of $\mathrm{SiO}_{2}^{\text {melt }}>60 \mathrm{wt} \%$ and $\mathrm{P}=150$ $500 \mathrm{MPa}$. Equations 3 and 4 yield similar pressure values, and we used the average value of both pressures, similar to the approach of Erdmann et al. (2014). We compared the glass and whole-rock compositions of Aso-4 pyroclasts (Kaneko et al. 2007) with experimental melts used for calibrations of Eqs. 1 and 2 by Putirka (2016) and for reliability evaluations of Eqs. 3 and 4 by Nagasaki et al. (2017) and confirmed that the compositions of Aso-4 magmas are within the range of the experimental melts (Additional file 2: Fig. S1); therefore, we concluded that applications of Eqs. 1-4 to Aso-4 pyroclasts are valid.

\section{Results and discussion}

Texture and compositions of amphibole phenocrysts

Aso-4 ejecta are crystal-poor with a modal abundance of phenocrysts of 5-10 vol\%, with the exception of scoriae with $10-37 \mathrm{vol} \%$ of phenocrysts (Kaneko et al. 2007). The studied 4I-1 pumice and welded tuff samples contain $\sim 0.3$ vol\% and $\sim 2.4$ vol\% amphibole phenocrysts, respectively. The pumice sample also contains phenocrysts of plagioclase ( $2.9 \mathrm{vol} \%)$, pyroxene ( $\sim 0.3 \mathrm{vol} \%)$, and $\mathrm{Fe}-\mathrm{Ti}$ oxides $(\sim 0.3$ vol\%) and trace apatite. Fe-Ti oxides do not show chemical zoning within crystal rims (Additional file 2: Fig. S2). Crystal clots composed of amphibole and other phenocryst phases such as plagioclase, Fe-Ti oxides and apatite were observed. In addition, some amphiboles host these phases as inclusions. However, we cannot find any glomeroporphyritic aggregate of pyroxene and amphibole crystals. Amphibole phenocrysts are euhedral with rare breakdown rims (Fig. 2a-c). The groundmass of the pumice sample is composed of vesicular glass and
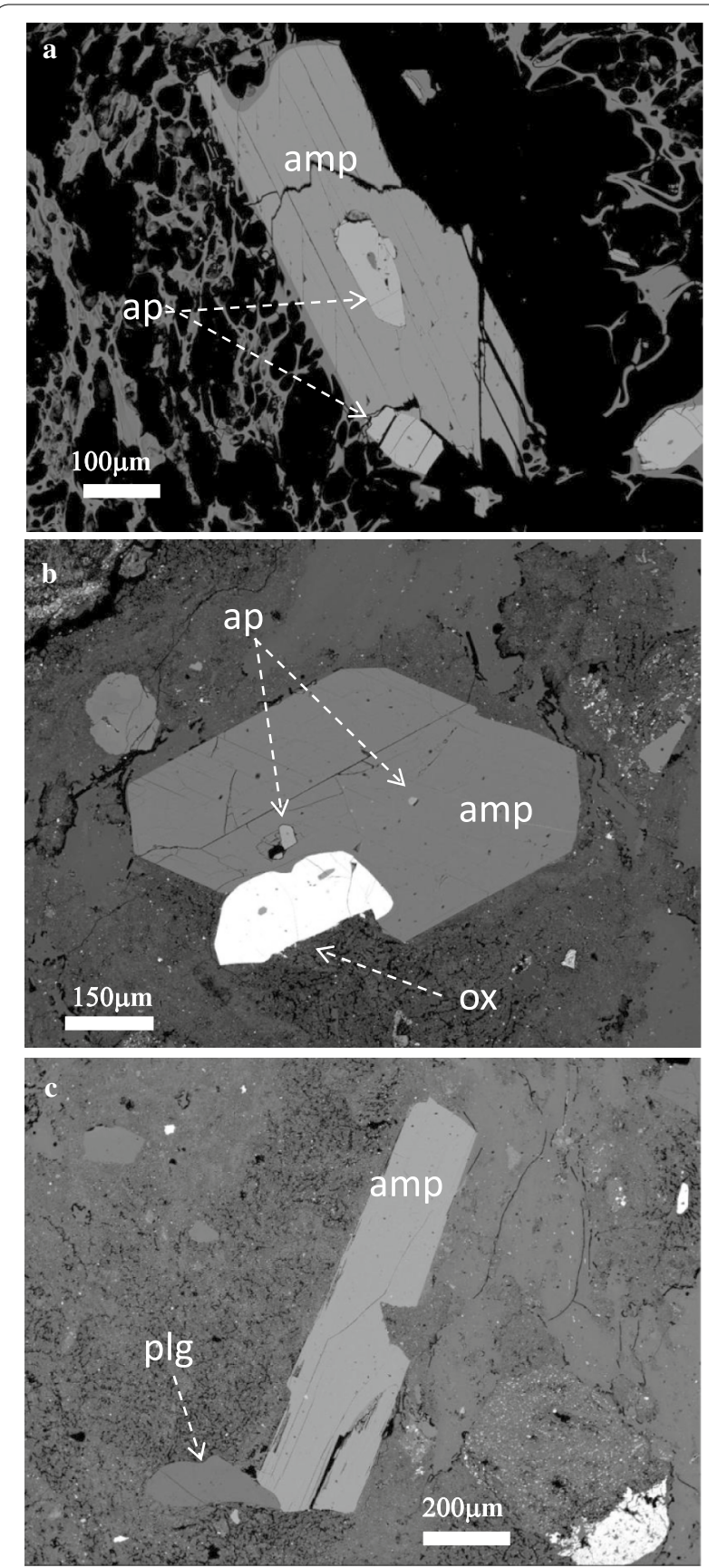

Fig. 2 BSE images of amphibole phenocrysts in samples: a 4I-1 $\mathrm{W}$ and b, c 4I-1p. Abbreviations are as follows: amphibole (amp), plagioclase (plg), Fe-Ti oxide (ox), and apatite (ap)

is microlite-free, indicating that crystallization did not occur during magma ascent within the conduit.

BSE images (Fig. 2) and EPMA analyses show that each amphibole phenocryst is almost chemically homogeneous, as described by Kaneko et al. (2007), although intergrain chemical variation is observed (Fig. 3 and Additional file 1: Table S1 and Additional file 2: Fig. S3). Based on the 


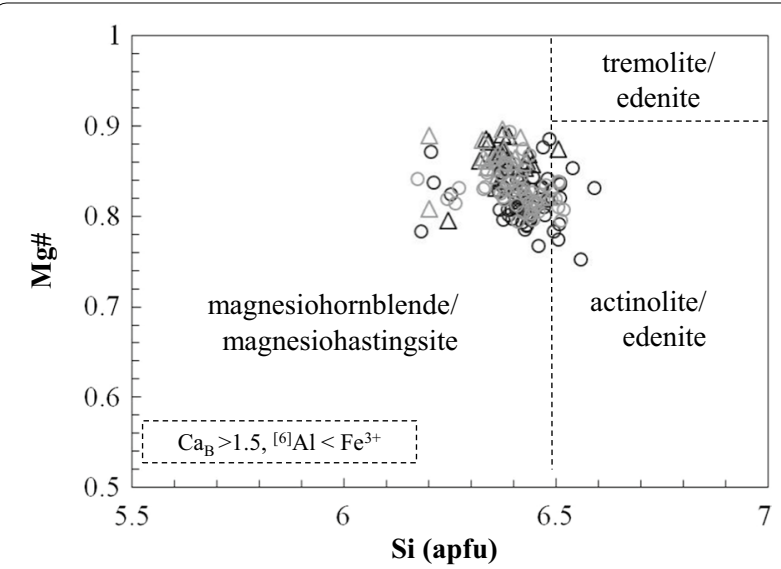

Fig. $3 \mathrm{Mg} \#\left[=\mathrm{Mg} /\left(\mathrm{Mg}+\mathrm{Fe}^{2+}\right)\right.$ on a molar basis $]$ plotted against $\mathrm{Si}$ (atoms per formula unit) for amphibole phenocrysts. Diamonds and circles indicate amphibole phenocrysts in samples 4I- $1 \mathrm{~W}$ and $4 \mathrm{I}-1 \mathrm{p}$, respectively. Black and gray symbols indicate the cores and rims of phenocrysts, respectively. Classification is based on Leake et al. (1997)

13-cation model of Leake et al. (1997), Ca and Ti contents are $>1.5$ and $<0.5 \mathrm{apfu}$, respectively, and the ${ }^{[6]} \mathrm{Al}$ content is lower than the $\mathrm{Fe}^{3+}$ content in all analyzed amphiboles. In addition, the $\mathrm{Si}$ content, $\mathrm{Mg} \#\left[=\mathrm{Mg} /\left(\mathrm{Mg}+\mathrm{Fe}^{2+}\right)\right]$, and $(\mathrm{Na}+\mathrm{K})^{\mathrm{A}}$ are 6.1-6.6, 0.75-0.9, and 0.4-0.5, respectively, where $(\mathrm{Na}+\mathrm{K})^{\mathrm{A}}$ is the total alkali content in the A site. According to the classification of Leake et al. (1997), the analyzed amphiboles are mostly magnesiohornblende or magnesiohastingsite, although rare actinolite and edenite amphiboles were also identified (Fig. 3).

${ }^{[4]} \mathrm{Al}$ ranges from $\sim 1.4$ to 1.9 apfu (Additional file 2: Fig. S3), which covers the full range of ${ }^{[4]} \mathrm{Al}$ contents previously reported in amphiboles in Aso-4 pyroclasts (Kaneko et al. 2007). Most amphiboles are characterized by a decrease in ${ }^{[6]} \mathrm{Al}$ content with a slight increase in ${ }^{[4]} \mathrm{Al}$ content, whereas amphiboles with ${ }^{[4]} \mathrm{Al}>\sim 1.7 \mathrm{apfu}$ are enriched in ${ }^{[6]} \mathrm{Al}$ (Additional file 2: Fig. S3a). No obvious correlation is found between ${ }^{[4]} \mathrm{Al}$ content and $(\mathrm{Na}+$ $\mathrm{K})^{\mathrm{A}}, \mathrm{Ti}$, and $\mathrm{Ca}$ contents (Additional file 2: Fig. S3b-d). In addition, ${ }^{[6]} \mathrm{Al}$ content shows a weak negative correlation with $\mathrm{Ti}$ and $\mathrm{Fe}^{3+}$ contents. These observations suggest that (1) the slight negative correlation between ${ }^{[4]} \mathrm{Al}$ and ${ }^{[6]} \mathrm{Al}$ is due to Ti-Tschermak and $\mathrm{Al}-\mathrm{Fe}^{3+}$ substitutions; (2) the Al-enriched nature of amphiboles with ${ }^{[4]} \mathrm{Al}>\sim 1.7$ apfu is due to Tschermak substitution; and (3) edenite and plagioclase substitutions are insignificant. Tschermak substitution is sensitive to both $\mathrm{T}$ and $\mathrm{P}$ conditions, whereas edenite and Ti-Tschermak substitutions are mostly temperature dependent (e.g., Anderson and Smith 1995; Shane and Smith 2013). Therefore, the crystallization $\mathrm{P}-\mathrm{T}$ conditions of the $\mathrm{Al}$-enriched amphiboles may be distinct from those of other amphiboles.

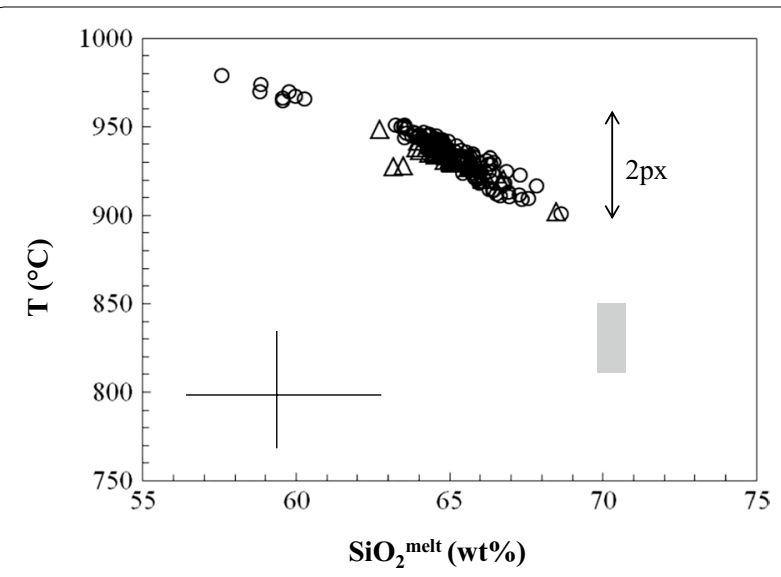

Fig. 4 Temperature conditions and $\mathrm{SiO}_{2}$ contents of hydrous melt in equilibrium with amphibole phenocrysts, as estimated using the methods of Putirka (2016). Diamonds and circles indicate amphibole phenocrysts in samples $4 \mathrm{I}-1 \mathrm{~W}$ and $4 \mathrm{I}-1 \mathrm{p}$, respectively. Error bars indicate $1 \sigma$ errors for estimations of temperature $\left( \pm 30^{\circ} \mathrm{C}\right)$ and $\mathrm{SiO}_{2}^{\text {melt }}$ ( $\pm 3 \mathrm{wt} \%$ ). Gray area shows the $\mathrm{T}-\mathrm{SiO}_{2}^{\text {melt }}$ conditions of the groundmass melt of the 4l-1 magma; the temperature is based on Fe-Ti oxide thermometry (from Kaneko et al. 2007).

The double-headed arrow indicates the range estimated using two-pyroxene thermometry (from Kaneko et al. 2007)

The Al-enriched amphiboles are rare in the 4I-1 pyroclasts, whereas other pyroclastic units of the Aso-4 eruption, which were hybrid of the 4I-1 magma and the mafic magma erupted as the 4I-3 and 4II-3 Units, commonly include them; on the other hand, the other amphiboles (with no $\mathrm{Al}$ enrichment) are common in the 4I-1 magma (Kaneko et al. 2007).

\section{$\mathrm{T}-\mathrm{SiO}_{2}^{\text {melt }}$ conditions of amphibole crystallization}

Figure 4 and Additional file 2: Fig. S4 show the $\mathrm{T}-\mathrm{SiO}_{2}^{\text {melt }}$ conditions of amphibole crystallization, as estimated from amphibole compositions. The estimated $\mathrm{T}-\mathrm{SiO}_{2}^{\text {melt }}$ conditions are homogenous from core to rim of each amphibole phenocryst, although inter-grain variation is observed (Additional file 2: Fig. S4). The estimated $\mathrm{SiO}_{2}^{\text {melt }}$ contents are $\sim 57-69 \mathrm{wt} \%$, with a gap at $\sim 60.5-$ $62.5 \mathrm{wt} \%$. The lower $\mathrm{SiO}_{2}^{\text {melt }}$ contents are estimated from Al-enriched amphiboles. The temperatures estimated from amphibole phenocrysts vary from $\sim 900$ to $980{ }^{\circ} \mathrm{C}$, and the $\mathrm{Al}$-enriched amphiboles yield higher temperatures $\left(\sim>960{ }^{\circ} \mathrm{C}\right)$. $\mathrm{SiO}_{2}^{\text {melt }}$ contents increase as temperature decreases (Fig. 4). The $\mathrm{T}-\mathrm{SiO}_{2}^{\text {melt }}$ gap between $\mathrm{Al}$-enriched and other amphiboles suggests that the two groups were crystallized under different conditions. We infer that the Al-enriched amphiboles were crystallized in andesitic melt formed by mixing between the 4I-1 melt and the mafic magma (erupted during the later stage of the Aso-4 eruption; Units 4I-3 and 4II-3) because similar 
Al-rich amphiboles are common in the pyroclastic units other than the 4I-1 (Kaneko et al. 2007). The other amphiboles (with no $\mathrm{Al}$ enrichment), commonly found in the 4I-1 magma, were not related to the mafic magma and were crystallized and accumulated within the main Aso-4 magma reservoir.

The calculated amphibole temperatures are much higher than those estimated from $\mathrm{Fe}-\mathrm{Ti}$ oxide thermometry $\left(810{ }^{\circ} \mathrm{C}-850{ }^{\circ} \mathrm{C}\right.$; Kaneko et al. 2007). Fe-Ti oxide thermometry is thought to reliably represent the pre-eruptive temperature of the 4I-1 melt (Kaneko et al. 2007) because the diffusion coefficient of $\mathrm{Ti}$ in $\mathrm{Fe}-\mathrm{Ti}$ oxides is large $\left(\sim 10^{-15} \mathrm{~m}^{2} / \mathrm{s}\right.$ at $830{ }^{\circ} \mathrm{C}$; Freer and Hauptman 1978) and chemical zoning is absent at the rims of $\mathrm{Fe}-\mathrm{Ti}$ oxide phenocrysts (Additional file 2: Fig. S2). The absence of chemical zoning in Fe-Ti oxide rims indicates that crystallization/re-equilibration did not occur during magma ascent, and hence, the $\mathrm{Fe}-\mathrm{Ti}$ oxides record the pre-eruptive temperature of the magma. The large discrepancy between amphibole and Fe-Ti oxide temperatures, as well as the intra-grain homogeneity of amphibole phenocrysts, suggests that the amphiboles were in disequilibrium with the 4I-1 melt.

Under hydrous conditions, the 4I-1 melt is characterized by $\sim 70 \mathrm{wt} \% \mathrm{SiO}_{2}^{\text {melt }}$ and $\sim 4.1-5.7 \mathrm{wt} \% \mathrm{H}_{2} \mathrm{O}$ (Kaneko et al. 2007). Most of the amphiboles indicate $\mathrm{SiO}_{2}^{\text {melt }}$ contents lower than that of the $4 \mathrm{I}-1$ melt, suggesting that they were in disequilibrium with the 4I-1 melt. This is consistent with the implications of the temperature estimations. Although a small number of amphiboles yield $\mathrm{SiO}_{2}^{\text {melt }}$ contents of coexisting melts within error of the 4I-1 melt, they show higher temperatures than that of the 4I-1 melt, suggesting that they were in disequilibrium with the melt. The interpretation of disequilibrium between the amphiboles and the host melt is consistent with the results of high-P-T equilibrium experiments on the Aso-4 magma (Ushioda et al. 2017). No amphibole with the composition of the 4I-1 melt crystallized in these experiments, even under a wide range of $\mathrm{P}-\mathrm{T}-\mathrm{H}_{2} \mathrm{O}$ conditions (Ushioda et al. 2017). In addition, a similar case of host melt-amphibole disequilibrium is reported from the 2015 rhyolitic magma from Cotopaxi, Ecuador (Martel et al. 2018).

\section{Origin of amphiboles}

Euhedral crystal shapes and the absence of overgrowth/ re-equilibration rims around amphibole phenocrysts suggest that they were entrained into the 4I-1 melt immediately before the Aso-4 eruption. Previous experiments showed that several days are required for the formation of amphibole breakdown rims during decompression without overheating (Rutherford and Hill 1993; Brown and Gardner 2006); the experiments of Brown and Gardner (2006) were performed at $840{ }^{\circ} \mathrm{C}$, which is similar to $\mathrm{Fe}-\mathrm{Ti}$ oxide temperature estimated for the 4I-1 magma (810-850 ${ }^{\circ} \mathrm{C}$; Kaneko et al. 2007). If an amphibole crystal is overheated, less than an hour is required to form a breakdown rim (De Angelis et al. 2015). Therefore, we conclude that the amphiboles were rapidly transported (possibly less than several days) to the surface after entrainment into the host 4I-1 melt.

Plagioclase, Fe-Ti oxide minerals, and apatite are often found in crystal clots with amphiboles and also as inclusions in amphiboles (Fig. 2). This suggests that some crystals of plagioclase, $\mathrm{Fe}-\mathrm{Ti}$ oxide minerals, and apatite likely had the same origin as the amphiboles and were entrained in the 4I-1 melt immediately before the eruption.

The calculated amphibole temperatures $\left(\sim 910-950^{\circ} \mathrm{C}\right)$ are similar to previous temperature estimates from two-pyroxene thermometry $\left(900-960{ }^{\circ} \mathrm{C}\right.$; Kaneko et al. 2007), which are higher than $\mathrm{Fe}-\mathrm{Ti}$ oxide temperatures (810-850 ${ }^{\circ} \mathrm{C}$; Kaneko et al. 2007). The two-pyroxene temperatures are based on the compositions of ortho- and clinopyroxene pairs, and Kaneko et al. (2007) confirmed a state of quasi-equilibrium between paired pyroxenes based on Fe-Mg partitioning. Kaneko et al. (2007) interpreted that the discrepancy between temperatures estimated using the Fe-Ti oxide and two-pyroxene thermometers is due to differences in closure temperatures between the two methods. If this interpretation is valid, the host melt and Fe-Ti oxides must have cooled rapidly to inhibit the formation of amphibole overgrowth/ re-equilibrated rims prior to magma ascent. High-P-T equilibrium experiments showed that crystallization of amphibole with crystal sizes $>10 \mu \mathrm{m}$ in silicic melt occurs within $\sim>10$ days (e.g., Holtz et al. 2005). Considering the diffusion coefficient of Ti in magnetite $\left(\sim 10^{-15} \mathrm{~m}^{2} / \mathrm{s}\right.$ at $830{ }^{\circ} \mathrm{C}$; Freer and Hauptman 1978), diffusion profiles of $\mathrm{Ti}$ with several tens of microns thickness should be observed in magnetite if the host melt was cooled during 1-10 days. However, such chemical zoning is not observed. Therefore, the discrepancy between temperatures estimated using the $\mathrm{Fe}-\mathrm{Ti}$ oxide and two-pyroxene thermometers cannot be attributed to differences in closure temperatures. Alternatively, we infer that some pyroxenes were also entrained into the 4I-1 melt immediately before eruption, as is the case for amphiboles, and the two-pyroxene temperatures record their thermal state before entrainment into the 4I-1 melt.

However, the similar temperature estimates from amphibole and pyroxene thermometry (Fig. 5) do not necessarily indicate co-crystallization of these phases in the same melt. This is because there is no pyroxene crystal touching with amphibole although other mineral phases are found as amphibole-hosted inclusions in the 4I-1 


\section{Mafic magma 78 Crystal mush \\ Crystal mush (+Amp) \\ $(+\mathrm{Opx}+\mathrm{Cpx} ;$ Amp-absent) \\ Cpx- and}
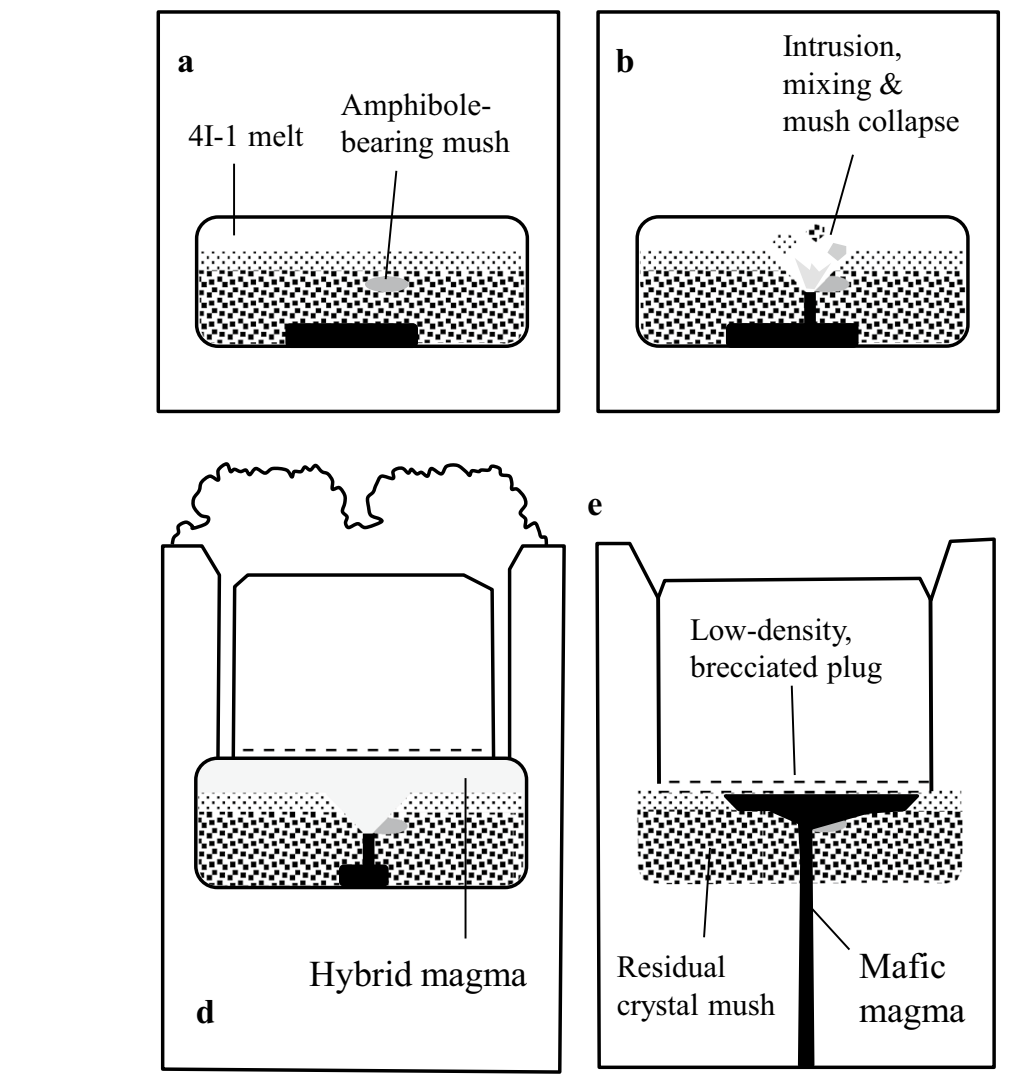
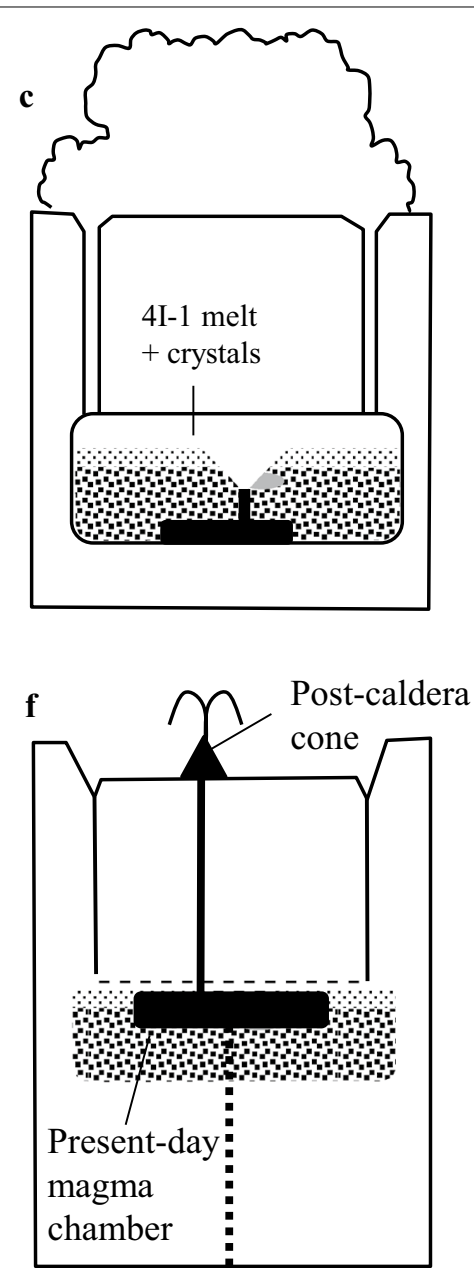

Fig. 5 Schematic diagrams showing a the state before the Aso-4 event started. Amphibole- and Cpx-free crystal mush underlying the $4 \mathrm{l}-1$ melt chamber and overlying two-pyroxene-bearing crystal mush with a local amphibole-bearing part; $\mathbf{b}$ the mafic magma started intrusion into the 4I-1 melt chamber. The initially intruded mafic magma was mixed with the 4l-1 melt to form small volume of hybrid magma, which crystallized Al-enriched amphiboles. In addition, the intrusion induced partial collapse of the crystal mush; $\mathbf{c}$ the hybrid magma and crystals derived from the collapsed mush were incorporated into and mixed with the $4 \mathrm{I}-1$ melt, and the magma erupted to form the $4 \mathrm{l}-1$ pyroclastic flow; $\mathbf{d}$ large volume of the mafic magma intruded into and mixed with the residual 4I-1 melt to form abundant hybrid magma, which erupted in the later stage of Aso-4 eruption; e after Aso eruption ended, low-density breccias and residual crystal mush acted as density barrier for ascending mafic magma, resulting in formation of mafic magma reservoir at the depth similar to the Aso-4 magma reservoir; $\mathbf{f}$ in post-caldera stage, mafic magmas derived from the new mafic magma reservoir have erupted

pyroclasts (Fig. 2), implying that amphibole and pyroxene did not coexisted. High-P-T equilibrium experiments for andesitic-dacitic systems (e.g., Costa et al. 2004; Scaillet and Ebans 1999; Moore and Carmichael 1998) show that amphibole crystallizes without pyroxene under relatively $\mathrm{H}_{2} \mathrm{O}$-rich condition, whereas amphibole is unstable and two pyroxenes crystallize under $\mathrm{H}_{2} \mathrm{O}$-poor condition at temperature of ca. $900-950{ }^{\circ} \mathrm{C}$. Under intermediate condition, amphibole and pyroxene can coexist. In addition, thermodynamic stability of amphibole also depends on melt composition (e.g., Putirka 2016). Therefore, the absence of touching amphibole-pyroxene pair, as well as similar temperatures of amphibole and pyroxenes, suggests that amphibole and pyroxenes crystallized from discrete melts of different $\mathrm{H}_{2} \mathrm{O}$ contents and/or compositions, and both crystals were entrained in the 4I-1 melt immediately before the eruption.

Previous studies have indicated that some phenocrysts in caldera-forming magma are derived from crystal mush surrounding the magma chamber (e.g., Cooper 2017; Ellis et al. 2014). This is also the case for the Aso-4 magma, as (1) amphibole, plagioclase, and $\mathrm{Fe}-\mathrm{Ti}$ oxide minerals sometimes occur as crystal clots, (2) both amphiboles and some pyroxenes were in disequilibrium 
with the 4I-1 melt, (3) amphiboles and pyroxenes in the 4I-1 pyroclasts were crystallized in the discrete melts of different $\mathrm{H}_{2} \mathrm{O}$ contents and/or compositions, and (4) amphiboles not enriched in $\mathrm{Al}$ are common in the 4I-1 magma. These evidences indicate that they were incorporated into the 4I-1 melt from crystal mush that accumulated beneath the 4I-1 magma chamber. The crystal mush was formed by the accumulation of mineral phases that crystallized within the Aso-4 magma reservoir. The accumulated crystal mush formed a thermal conduction layer at the base of the reservoir that inhibited cooling from the base. As a result, the magma reservoir cooled only from the roof and the underlying crystal mush layer had a higher temperature than the overlying magma chamber (e.g., Nishimura 2012). Therefore, the temperatures of the underlying crystal-mush-derived amphiboles are higher than those of the overlying 4I-1 melt.

We suggest that the 4I-1 magma chamber and the underlying amphibole-bearing crystal mush part were separated by a lower- $\mathrm{T}$ amphibole-free crystal mush layer. The interstitial melt in the amphibole-free crystal mush may have filled the thermal-compositional gap between the 4I-1 melt and the melts in equilibrium with amphiboles. In addition, the lower-T amphibolefree crystal mush layer was also clinopyroxene-free because of the lack of ortho- and clinopyroxene pair revealing temperature $<900{ }^{\circ} \mathrm{C}$ (Kaneko et al. 2007). This is supported by the results of high-P-T equilibrium experiments for hydrous dacitic system (Costa et al. 2004); the results show that (1) ortho- and clinopyroxenes coexist at relatively high temperatures $\left(>900{ }^{\circ} \mathrm{C}\right)$, (2) orthopyroxene crystallizes without both clinopyroxene and amphibole under relatively low temperature $\left(<900{ }^{\circ} \mathrm{C}\right)$ and intermediate-low $\mathrm{H}_{2} \mathrm{O}$ content conditions (<ca. $4.5 \mathrm{wt} \% \mathrm{H}_{2} \mathrm{O}$ in melt), and (3) amphibole crystallizes even at lower temperature $\left(<900{ }^{\circ} \mathrm{C}\right)$ under $\mathrm{H}_{2} \mathrm{O}$-rich condition (<ca. $4.5 \mathrm{wt} \% \mathrm{H}_{2} \mathrm{O}$ in melt), although the boundary $\mathrm{T}-\mathrm{H}_{2} \mathrm{O}$ conditions may shift slightly with the change in melt composition. The absence of amphibole with $T<910{ }^{\circ} \mathrm{C}$ indicates that the amphibole-free mush layer was not $\mathrm{H}_{2} \mathrm{O}$-rich. This is consistent with the estimation of $\mathrm{H}_{2} \mathrm{O}$ content in the 4I-1 melt (ca. 4.1-5.7 wt\%) based on plagioclase-melt element partitioning (Kaneko et al. 2007), which is near the lower limit of amphibole stability field. Interstitial melt in the underlying hotter crystal mush is inferred to be less evolved and less hydrous than the 4I-1 melt. Consequently, we think that the crystal mush underlying the 4I-1 melt chamber was under intermediate-low $\mathrm{H}_{2} \mathrm{O}$ content condition and included orthopyroxene at lower $T$ and two-pyroxene assemblage was limited to higher- $T$ conditions. In the crystal mush, $\mathrm{H}_{2} \mathrm{O}$-rich part including amphibole without pyroxenes locally existed
(Fig. 5a). Similar model of heterogeneous mushy reservoir was suggested for Central Snake River Plain ignimbrites (Ellis et al. 2014). In the case of the Aso-4 eruption, partial collapse of the crystal mush may have occurred immediately prior to eruption. This is because the $4 \mathrm{I}-1$ pyroclasts include both amphiboles and pyroxenes stored in separated parts of the underlying crystal mush, and residence times of amphiboles in the 4I-1 melt were short. If we assume all phenocrysts were derived from the crystal mush and the crystal mush contained $>60 \mathrm{vol} \%$ of crystals, the volume ratio of collapsed crystal mush to the 4I-1 melt is estimated to be less than $\sim 0.15$. Therefore, the collapsed mush was limited to the part only near the 4I-1 melt chamber. We attribute this collapse to the injection of mafic magma prior to eruption, as inferred from the Al-enriched amphiboles of the 4I-1 pyroclasts, which are in equilibrium with higher-T andesitic melt (Fig. 4). Among the four caldera-forming ignimbrites, only the Aso-4 pyroclasts contain amphibole phenocrysts. We attribute this to the following: (1) The crystal mush had an amphibole-bearing part locally only before Aso-4 eruption and/or (2) because of the larger magnitude of the Aso-4 eruption compared to other ignimbrite eruptions, the collapsed mush was large volume enough to include a locally distributed amphibole-bearing part.

Kaneko et al. (2007) suggested that following the 4I-1 eruption, the 4I-1 melt and the underlying mafic melt mixed to form less-silicic hybrid magma, which then erupted during the later Stages 4I-2 and 4II of the Aso-4 eruption (4II of Kaneko et al. 2007). We infer that the mafic magma was derived from another magma pocket located in the bottom part of the crystal mush or underlying Aso-4 magma reservoir (Fig. 5a). Initial intrusion of the mafic magma induced partial collapse of the crystal mush underlying the 4I-1 melt chamber. Furthermore, the intruding mafic magma rapidly mixed with the 4I-1 melt to form andesitic melt which crystallized the Alrich amphiboles (Fig. 5b). Experimental study of Kouchi and Sunagawa (1985) showed that when basaltic and silicic melts are mixed, basaltic melt rapidly changes to andesitic composition by mixing with silicic melt, whereas silicic melt decreases its mass without significant compositional change. Therefore, at this time, abundance of the hybrid andesitic melt was very small relative to the 4I-1 melt and exerted negligible effect on the 4I-1 melt composition. Then, the small volume of the Al-enriched amphibole-bearing andesitic melt was mixed with the more voluminous 4I-1 melt and the crystal-mush-derived crystals; the magma erupted and formed the 4I-1 pyroclastic flow deposit (Fig. 5c). In the later stage of Aso-4 eruption, more abundant mafic magma was intruded and mixed with the 4I-1 melt to form the hybrid dacitic 
melts, which erupted as the 4I-2 and 4II Units as Kaneko et al. (2007) discussed (Fig. 5d).

\section{Pressure conditions of amphibole crystallization}

The amphibole barometer of Ridolfi and Renzulli (2012) indicates crystallization pressures of $\sim 260-380 \mathrm{MPa}$ for most amphiboles. This is within error of the pressures calculated for the Al-enriched amphiboles ( 340$420 \mathrm{MPa}$; Fig. 6; based on the $\pm 85 \mathrm{MPa}(1 \sigma)$ error for the barometer; Nagasaki et al. 2017).

Assuming a lithostatic pressure-depth relation and a crust density of $2500 \mathrm{~kg} / \mathrm{m}^{3}$, the pressure of $\sim 340 \pm 85 \mathrm{MPa}$ corresponds to $\sim 13.9 \pm 3.5 \mathrm{~km}$ depth. The crust density is consistent with the reported rock types (granodiorite and psammitic schist) of borehole core samples from the basement of Aso caldera (Miyoshi et al. 2011a). The lithostatic pressure-depth is consistent with a previous estimation of the pre-eruptive depth of the Aso-4 silicic magma at $>3 \mathrm{~km}$ (based on the water content of the melt and the $\mathrm{H}_{2} \mathrm{O}$ solubility equation; Kaneko et al. 2007).

The geophysical study of Abe et al. (2016) reported a low-velocity zone at a depth of $8-15 \mathrm{~km}$ beneath the eastern flank of the post-caldera central cones, a swarm of deep low-frequency earthquakes at $15-25 \mathrm{~km}$ depth, and a sill-like deformation source at $15.5 \mathrm{~km}$ depth. These results suggest that a magma reservoir exists at depths of $8-15 \mathrm{~km}$, which is consistent with our amphibole barometry results (Fig. 6). This indicates that the Aso-4 magma reservoir was located at a depth similar to that of the present-day magma reservoir beneath Aso Volcano.

Most of the magmas that erupted after the last calderaforming eruption have basaltic-andesitic compositions (Miyoshi et al. 2012), and the present-day magma chamber is thought to contain mafic magma (Unglert et al.

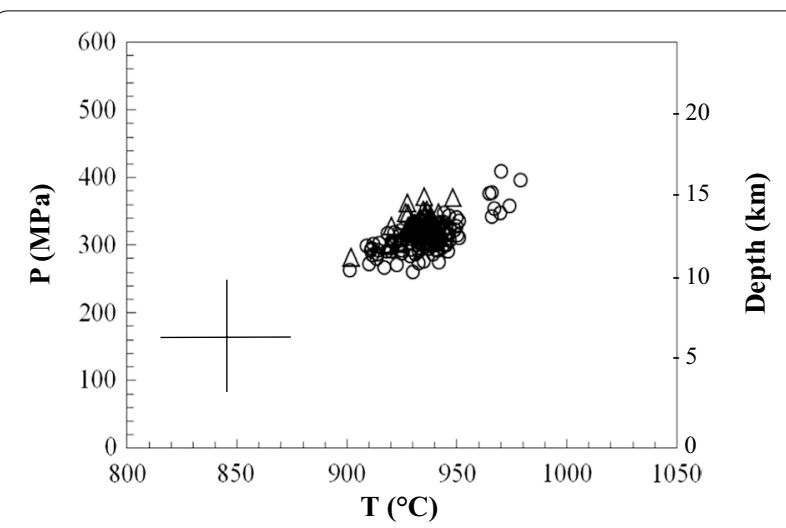

Fig. 6 Pressure-temperature conditions estimated from amphibole compositions. Symbols are as shown in Fig. 4. Depth is calculated from pressure under an assumption of crust density $\sim 2500 \mathrm{~kg} / \mathrm{m}^{3}$
2011). This suggests that the present magma plumbing system was formed after the Aso-4 eruption. The consistency between the depths of the Aso- 4 and the presentday magma reservoirs may imply that the depth of the present-day magma reservoir is strongly influenced by the structure of the Aso-4 magma reservoir. We suggest that the relic of the Aso-4 magma reservoir created a density barrier that inhibited the ascent of newly supplied post-caldera mafic magmas, meaning that they resided at the depth (Fig. 5e, f). After caldera collapse, the collapsed magma reservoir was filled by low-density breccia (e.g., Lipman 1984), which is less dense than mafic magma and hence acted as a density barrier. The crystal mush layer that remained beneath the collapsed magma reservoir further inhibited the ascent of post-caldera mafic magmas. The Aso-4 ejecta are crystal-poor ( 5-10 vol\%; Kaneko et al. 2007; with the exception of scoriae); consequently, a large part of the crystal mush layer is thought to have remained. The crystal mush consisted of andesitic-dacitic melt, plagioclase, and mafic minerals, with density similar to, or lower than, that of mafic melt. As a result, sills of dense mafic magma formed at a similar depth to that of the 4I-1 magma chamber. The postcaldera mafic magmas may have chemically interacted with the remaining crystal mush, although the Aso- 4 and post-caldera basaltic-andesitic magmas have similar isotopic compositions (Miyoshi et al. 2011b); consequently, their interaction is difficult to detect using isotopic data. The formation and differentiation of mafic sills at depth also created additional barriers for the ascending mafic magma. Our results indicate that the post-caldera magma plumbing system was strongly influenced by the collapsed silicic magma reservoir that remained after the Aso-4 caldera-forming eruption.

\section{Concluding remarks}

Chemical compositions of amphibole phenocrysts in Aso-4I pyroclasts were investigated to clarify their crystallization conditions and pre-eruptive magmatic processes. Our results suggest the following: (1) Most of the amphibole phenocrysts coexisted with silicate melt with $66-72 \mathrm{wt} \% \mathrm{SiO}_{2}$ and temperatures of $910-950{ }^{\circ} \mathrm{C}$, whereas some amphiboles crystallized from more mafic and higher-T melt; (2) the amphibole phenocrysts are in thermal and chemical disequilibrium with the host 4I-1 melt, indicating that they were incorporated into the melt immediately prior to eruption; and (3) amphibole phenocrysts crystallized at a depth of $\sim 13.9 \pm 3.5 \mathrm{~km}$, which coincides with the depth of the present low-velocity zone beneath the volcano, implying that the depth of the postcaldera magma plumbing system is strongly influenced by a relic collapsed magma reservoir related to the most 
recent caldera-forming eruption. In future study, compositional analyses of minerals and melt inclusions coexisting with amphiboles in the 4I-1 and other units of Aso-4 eruption should be required to evaluate and brush up the model of Aso-4 magma reservoir process.

\section{Additional files}

Additional file 1: Table S1. Major-element compositions of amphibole phenocrysts in this study.

Additional file 2: Fig. S1. Whole-rock and melt compositions of Aso-4 pyroclasts are compared with those of melts of equilibrium experiments used for calibrations of amphibole-based thermometer and melt-SiO meter of Putirka (2016) and for reliability evaluation of amphibole-based barometer of Ridorfi and Renzulli (2012) by Nagasaki et al. (2017). Filled circles and open triangles indicate glass and whole-rock compositions of Aso-4 pyroclasts (Kaneko et al. 2007), and gray diamonds are experimental melts (DS-1 dataset compiled by Putirka 2016; see Putirka 2016 and references therein). Compositions of Aso-4 pyroclastic materials are within the range of experimental melts. Fig. S2. BSE images of magnetite phenocrysts in the studied pumice sample. Fig. S3. Amphibole compositions in terms of the relationship between ${ }^{\left[{ }^{[4]}\right.} \mathrm{Al}$ and $(\mathrm{a}){ }^{[6]} \mathrm{Al}$, (b) $(\mathrm{Na}+\mathrm{K})^{\mathrm{A}}$, (c) $\mathrm{Ti}$, and (d) Ca. Symbols are the same as those in Fig. 3. Fig. S4. Comparisons of (a) temperatures and (b) $\mathrm{SiO}_{2}^{\text {melt }}$ contents estimated from the core and rim compositions of amphiboles. Diamonds and circles indicate amphibole phenocrysts in samples $4 \mathrm{I}-1 \mathrm{w}$ and $4 \mathrm{I}-1 \mathrm{p}$, respectively.

\section{Authors' contributions}

HI participated in the design of the study, carried out field surveys for collecting the studied samples, microscopic observation and EMP analyses of the studied samples, geothermobarometric and chemometric data analyses, and drafted the manuscript. YS carried out sample preparations for SEM observations and EMP analyses and carried out geothermobarometric and chemometric data analyses. MM participated in the design of the study, carried out field surveys for collecting the studied samples, and drafted the manuscript. AY participated in the design of the study, carried out EMP analyses of the studied samples, and drafted the manuscript. NH carried out SEM observations and EMP analyses of the studied samples. All authors read and approved the final manuscript.

\section{Author details}

1 Department of Geoscience, Faculty of Science, Shizuoka University, Ohya 836, Suruga-ku, Shizuoka 422-8529, Japan. ${ }^{2}$ Faculty of Education, University of Fukui, 3-9-1 Bnkyo, Fukui-shi, Fukui 910-8507, Japan. ${ }^{3}$ Earthquake Research Institute, University of Tokyo, 1-1-1 Yayoi, Bunkyo-ku, Tokyo 111-0032, Japan.

\section{Acknowledgements}

We are grateful to the editor Dr. A. Yokoo and two reviewers, Dr. K. Kaneko and an anonymous reviewer, who provided thoughtful comments that have improved the manuscript to an enormous degree. We thank Ms. Y. Kakihata for her helpful support of SEM observation at Shizuoka University.

\section{Competing interests}

The authors declare that they have no competing interests.

\section{Availability of data and materials}

Please contact author for data requests.

\section{Funding}

This study was supported by grants from JSPS KAKENHI (JP16K05606), the Earthquake Research Institute Cooperative Program (2017-G-03), and the Integrated Program for Next Generation Research and Human Resource Development.

\section{Publisher's Note}

Springer Nature remains neutral with regard to jurisdictional claims in published maps and institutional affiliations.

Received: 29 March 2018 Accepted: 11 August 2018

Published online: 23 August 2018

\section{References}

Abe Y, Ohkura T, Shibutani T, Hirahara K, Yoshikawam S, Inoue H (2016) Lowvelocity zones in the crust beneath Aso caldera, Kyushu, Japan, derived from receiver function analyses. J Geophys Res Solid Earth. https://doi. org/10.1002/2016JB013686

Anderson JL, Smith DR (1995) The effects of temperature and $\mathrm{fO}_{2}$ on the Al-inhornblend barometer. Am Miner 80:549-559

Blundy JD, Holland TJB (1990) Calcic amphibole equilibria and a new amphibole-plagioclase geothermometer. Contrib Miner Petrol 104(2):208-224

Brown LB, Gardner JE (2006) The influence of magma ascent path on the texture, mineralogy, and formation of hornblende reaction rims. Earth Planet Sci Lett 246:161-176

Committee for Catalog of Quaternary Volcanoes in Japan (1999) Catalog of quaternary volcanoes in Japan. Ver. 1.0. The Volcanological Society of Japan, CD-ROM

Cooper KM (2017) What does a magma reservoir look like? The "Crystal's-Eye" view. Elements 13:23-28

Costa F, Scaillet B, Pichavant M (2004) Petrological and experimental constraints on the pre-eruption conditions of Holocene dacite from Volcán San Pedro ( $36^{\circ} \mathrm{S}$, Chilean Andes) and the importance of sulphur in silicic subduction-related magmas. J Petrol 45:855-881

De Angelis SH, Larsen J, Coombs M (2013) Pre-eruptive magmatic conditions at Augustine volcano, Alaska, 2006: evidence from amphibole geochemistry and textures. J Petrol 54:1939-1961

De Angelis SH, Larsen J, Coombs M, Dunn A, Hayden L (2015) Amphibole reaction rims as a record of pre-eruptive magmatic heating: an experimental approach. Earth Planet Sci Lett 426:235-245

Druitt TH, Costa F, Deloule E, Dungan M, Scaillet B (2012) Decadal to monthly timescales of magma transfer and reservoir growth at a caldera volcano. Nature. https://doi.org/10.1038/nature10706

Ellis BS, Bachmann O, Wolff JA (2014) Cumulate fragments in silicic ignimbrites: the case of the Snake River Plain. Geology 42:431-433

Erdmann S, Martel C, Pichavant M, Kushnir A (2014) Amphibole as an archivist of magmatic crystallization conditions: problems, potential, and implications for inferring magma storage prior to the paroxysmal 2010 eruption of Mount Merapi, Indonesia. Contrib Mineral Petrol 167:1016

Freer R, Hauptman Z (1978) An experimental study of magnetite-ilmenite interdiffusion. Phys Earth Planet Inter 16:223-231

Ginibre C, Wörner G, Kronz A (2007) Crystal zoning as an archive for magma evolution. Elements 3:261-266

Holland T, Blundy J (1994) Non-ideal interactions in calcic amphiboles and their bearing on amphiboleplagioclase thermometry. Contrib Miner Petrol 116(4):433-447

Holtz F, Sato H, Lewis J, Behrens H, Nakada S (2005) Experimental petrology of the 1991-1995 Unzen dacite, Japan. Part I: phase relations, phase composition and pre-eruptive conditions. J Petrol 46:319-337

Hunter AG (1998) Intracrustal controls on the coexistence of tholeiitic and calc-alkaline magma series at Aso Volcano, SW Japan. J Petrol 39:1255-1284

Kamata H (1997) Geology of the Miyanoharu district. With geological sheet map at 1:50000, Geological Survey of Japan, 127p (in Japanese with English abstract 5p)

Kaneko K, Kamata H, Koyaguchi T, Yoshikawa M, Furukawa K (2007) Repeated large-scale eruptions from a single compositionally stratified magma chamber: an example from Aso volcano, Southwest Japan. J Volcanol Geotherm Res 167:160-180

Kiss B, Harangi S, Ntaflos T, Mason PRD, Pál-Molnár E (2014) amphibole perspective to unravel pre-eruptive processes and conditions in volcanic plumbing systems beneath intermediate arc volcanoes: a case study from Ciomadul volcano (SE Carpathians). Contrib Mineral Petrol 167:986 
Kouchi A, Sunagawa I (1985) A model for mixing basaltic and dacitic magmas as deduced from experimental data. Contrib Mineral Petrol 89:17-23

Leake BE, Woolley AR, Arps CES, Birch WD, Gilbert MC, Grice JD, Hawthorne FC, Kato A, Kisch HJ, Krivovichev VG et al (1997) Nomenclature of amphiboles: report of the subcommittee on amphiboles of the International Mineralogical Association, Commission on New Minerals and Mineral Names. Can Mineral 35:219-246

Lipman P (1984) The roots of ash flow calderas in western north America: windows into the tops of granitic batholiths. J Geophys Res 89:8801-8841

Machida H, Arai F (2003) Atlas of tephra in and around Japan. University of Tokyo Press, Tokyo, p 336 (in Japanese)

Martel C, Andújar J, Mothes P, Scaillet B, Pichavant M, Molina I (2018) Storage conditions of the mafic and silicic magmas at Cotopaxi, Ecuador. J Volcanol Geotherm Res 354:74-86

Matsumoto A, Uto K, Ono K, Watanabe K (1991) K-Ar age determinations for Aso volcanic rocks-concordance with volcanostratigraphy and application to pyroclastic flows. Program Abstr Volcanol Soc Jpn 2:73 (in Japanese)

Miller CF, Wark DA (2008) Supervolcanoes and their explosive supereruptions. Elements 4:11-15

Miyoshi M, Yuguchi T, Shinmura T, Mori Y, Arakawa Y, Toyohara F (2011a) Petrological characteristics and K-Ar age of borehole core samples of basement rocks from the northwestern caldera floor of Aso, central Kyushu. J Geol Soc Jpn 117:585-590

Miyoshi M, Shibata T, Yoshikawa M, Sano T, Shinmura T, Hasenaka T (2011 b) Genetic relationship between post-caldera and caldera-forming magmas from Aso volcano, SW Japan: constraints from Sr isotope and trace element compositions. J Mineral Petrol Sci 106:114-119

Miyoshi M, Sumino H, Myabuchi Y, Sinmura T, Mori Y, Hasenaka T, Furukawa K, Uno K, Nagao K (2012) K-Ar ages determined for post-caldera volcanic products from Aso volcano, central Kyushu, Japan. J Volcanol Geotherm Res 229-230:64-73

Molina JF, Moreno JA, Castro A, Rodríguez C, Fershtater GB (2015) Calcic amphibole thermobarometry in etamorphic and igneous rocks: new calibrations based on plagioclase/amphibole Al-Si partitioning and amphibole/liquid Mg partitioning. Lithos 232:286-305

Moore G, Carmichael ISE (1998) The hydrous phase equilibria (to 3 kbar) of an andesite and basaltic andesite from western Mexico: constraints on water content and conditions of phenocryst growth. Contrib Mineral Petrol 130:304-319

Nagasaki S, Ishibashi H, Suwa Y, Yasuda A, Hokanishi N, Ohkura T, Takemura K (2017) Magma reservoir conditions beneath Tsurumi volcano, SW Japan: evidence from amphibole thermobarometry and seismicity. Lithos 278-281:153-165

Nishimura K (2012) Acceleration and deceleration of crystal settling in convecting silicic magma chambers. J Toyo Univ Nat Sci 56:19-30 (in Japanese with English abstract)
Ono K, Watanabe K (1983) Aso caldera. Earth Mon 5:73-82 (in Japanese)

Ono K, Watanabe K (1985) Geological map of Aso volcano (1:50,000). Geological map of volcanoes 4, Geological Survey of Japan (in Japanese with English abstract)

Ono K, Matsumoto Y, Miyahisa M, Teraoka Y, Kambe N (1977) Geology of the Taketa district. With geological sheet map at 1:50000, Geological Survey of Japan, p 157 (in Japanese with English abstract 8p)

Putirka K (2016) Amphibole thermometers and barometers for igneous systems and some implications for eruption mechanisms of felsic magmas at arc volcanoes. Am Mineral 101:851-858

Ridolfi F, Renzulli A (2012) Calcic amphiboles in calc-alkaline and alkaline magmas: thermobarometric and chemometric empirical equations valid up to $1,130{ }^{\circ} \mathrm{C}$ and $22 \mathrm{GPa}$. Contrib Mineral Petrol 163:877-895

Ridolfi F, Renzulli A, Puerini M (2010) Stability and chemical equilibrium of amphibole in calc-alkaline magmas: an overview, new thermbarometric formulations and application to subduction-related volcanoes. Contrib Mineral Petrol 160:45-66

Ruprecht P, Bachmann O (2010) Pre-eruptive reheating during magma mixing at Quizapu volcano and the implications for the explosiveness of silicic arc volcanoes. Geology 38:919-922

Rutherford MJ, Hill PM (1993) Magma ascent rates from amphibole breakdown: an experimental study applied to the 1980-1986 Mount St. Helens eruptions. J Geophys Res 98:19667-19685

Scaillet B, Ebans BW (1999) The 15 June 1991 eruption of Mount Pinatubo. I. Phase equilibria and pre-eruptive $P$ - $T$ - $f \mathrm{O} 2-\mathrm{fH}_{2} \mathrm{O}$ conditions of the dacite magma. J Petrol 40:381-411

Shane P, Smith VC (2013) Using amphibole crystals to reconstruct magma storage temperatures and pressures for the post-caldera collapse volcanism at Okataina volcano. Lithos 156-159:159-170

Unglert K, Savage MK, Fournier N, Ohkura T, Abe Y (2011) Shear wave splitting, $\mathrm{v}_{\mathrm{p}} / \mathrm{v}_{\mathrm{s}^{\prime}}$ and GPS during a time of enhanced activity at Aso caldera, Kyushu. J Geophys Res 116:B11203. https://doi.org/10.1029/2011JB008520

Ushioda M, Miyagi I, Suzuki T, Takahashi E (2017) Pre-eruptive P-T conditions and $\mathrm{H}_{2} \mathrm{O}$ concentration of Aso-4 silicic magma based on high pressure experiments. IAVCEI 2017 abstract

Wark DA, Hildreth W, Spear FS, Cherniak DJ, Watson EB (2007) Pre-eruptive recharge of the Bishop magma system. Geology 35:235-238

Watanabe K (1978) Studies on the Aso pyroclastic flow deposits in the region to the west of Aso caldera, southwest Japan, I: geology. Memorial of the Faculty of Education, Kumamoto University. Nat Sci 27:97-120

Watanabe K (2001) History and activity of Aso volcano (Japanese title "Aso kazan no oitachi"). Ichinomiya-cho, Japan (in Japanese)

Watanabe K, Itaya T, Ono K, Takada H (1989) K-Ar ages of dike rocks in the Southwestern region of Aso Caldera, Kyushu, Japan. KAZAN 34:189-195

\section{Submit your manuscript to a SpringerOpen ${ }^{\circ}$ journal and benefit from:}

- Convenient online submission

- Rigorous peer review

- Open access: articles freely available online

- High visibility within the field

- Retaining the copyright to your article

Submit your next manuscript at $\boldsymbol{\nabla}$ springeropen.com 